\title{
Statistical Modeling and Optimization of Biodiesel Production from Azadirachta Indica (Neem) Using Co-Solvent Technique
}

\author{
Nnodim $^{1}$ C. J., Nwakaudu ${ }^{1}$ M. S., Kamen ${ }^{1}$ F. L., Nwakaudu ${ }^{1}$ A. A., Ikhazuangbe ${ }^{1}$ P.M.O., \\ Haruna $^{2} \mathrm{I}$.
}

${ }^{1}$ Department of Chemical Engineering, Federal University of Technology, Owerri, Nigeria

${ }^{2}$ Petrochemicals and allied department National Research Institute for Chemical Technology, Zaria, Nigeria

\begin{abstract}
In this work, statistical modeling and optimization of biodiesel production from Azadirachta Indica(neem) using co-solvent technique via a two-step transesterification process was carried out. Neem oil was extracted from neem seeds and properties such as moisture content, specific gravity, acid value, saponification value and iodine value were determined. The experimental design used was Central Composite Design. The range of factor levels used for the Central Composite Design were reaction temperature $\left(30^{\circ} \mathrm{C}\right.$ to $\left.46^{\circ} \mathrm{C}\right)$, catalyst amount $(0.8 \%$ to $1.2 \%, w / w)$, reaction time (20 to 40min) and methanol-tooil molar ratio (5:1 to 9:1). The co-solvents used were methanol and diethyl ether. The co-solvent-to-methanol volume ratio for all the experimental runs was kept constant at 1:1. Also the biodiesel produced was characterized for some important properties including acid value, specific gravity, saponification value, iodine value, cetane number, ester value, kinematic viscosity, flash point, pour point and cloud point. Optimized biodiesel yield of $84.77 \%$ was obtained for reaction time of $35 \mathrm{~min}$, catalyst amount of $1.10 \mathrm{~g}$, reaction temperature of $34^{\circ} \mathrm{C}$, and oil-to-methanol molar ratio of 6:1. The cetane number (51.733), specific gravity $\left(0.8881 \mathrm{~g} / \mathrm{cm}^{3}\right)$, flash point $\left(134^{\circ} \mathrm{C}\right)$ and kinematic viscosity $\left(5.86 \mathrm{~mm}^{2} / \mathrm{s}\right)$ of the produced biodiesel met the ASTM specifications. The results of characterization of the biodiesel revealed that biodiesel can be produced at lower reaction conditions and with comparable fuel property with biodiesel produced using conventional methods.
\end{abstract}

Keywords-Biodiesel, Co-solvent, Modeling, Optimization, Transesterification.

\section{INTRODUCTION}

The continual degradation of the environment by pollutants associated with the combustion of fossil fuels remains a great challenge to the society and researchers have continued to develop alternative cleaner and cheaper fuels to fossil fuels. Among the various alternatives, biodiesel has received greater interest. Biodiesel is an alkyl ester(usually mono-alkyl ester) derived from vegetable oils through transesterification process between triglycerides and alcohol solvent (usually methanol solvent) in the presence of acid or alkaline catalyst. Short-chain alcohols such as methanol, ethanol and butanol are the most frequently employed. Selection of the alcohol is based on cost and performance consideration [11]. Methanol was dominating in most of the literature reviewed $[6,7,11,12]$. Methyl, rather than ethyl, ester production is usually prevalent because methyl esters are the predominant commercial products. Methanol is considerably cheaper and more available than ethanol and the downstream recovery of un-reacted alcohol is much easier (Pinto et al., 2005). Ethanol maintains its capability of being renewable as an advantage.

Biodiesel have been produced from different vegetable oils like Jatropha, mustard, chicken fat, waste vegetable oil, cotton seed and neem[1,4,5,6,7,8]. Biodiesel can be used to power diesel engine vehicles as its fuel properties has been shown to be comparable with those of petroleum diesel[2,4]. The effects of process variables on the yield of biodiesel has been studied and it has been showed that the major factors that affect the yield of biodiesel are: methanol-to-oil molar ratio, catalyst weight, reaction temperature and reaction time [8].

Researchers have investigated and developed various techniques and strategies for optimization of biodiesel production process in Nigeria in order to justify its feasibility and economic viability for adoption and commercialization as an alternative fuel and fuel blend(1). Various optimum conditions for biodiesel production have been obtained by researchers using conventional solvents 
[4,6,7]. Also biodiesel has been produced from different oils by several researchers using alkaline-catalized transesterification process in the presence of co-solvents, and the transesterification process has been shown to take place at lower reaction temperature and shorter time $[2,3,4,5]$.

Since the presence of co-solvent allows the transesterification process to take place at lower temperature and in a shorter time, there is need to optimize the reaction conditions that affect the yield of biodiesel in other to evaluate the economic viability of biodiesel production with neem oil using co-solvents. The aim of this work is to optimize biodiesel production from Azadirachta Indica (neem) using co-solvent technique.

\section{MATERIALS AND METHODS}

The major raw materials used for this work are neem oil, methanol and diethyl ether. The seeds were cleaned to remove the dirt and impurities contained in them. The oil was extracted from the neem seeds using a screw oil expeller machine (model: 6YL-100).

\section{Experimental design}

A four-factor-five-level central composite design was employed for this study, which generated thirty experimental runs. The factors investigated in this study were methanol-to-oil mole ratio, catalyst amount (w/w), reaction temperature $\left({ }^{\circ} \mathrm{C}\right)$ and reaction time (minutes). The experimental range and Levels of the independent variables are shown in Table 1 below.

Table.1: Experimental Range and Levels of the Independent Variables

\begin{tabular}{|l|l|c|c|c|c|c|}
\hline & Symbols & \multicolumn{2}{l|}{ Coded factor levels } \\
\hline Variables & & low (-1) & & 0 & & High (+1) \\
\hline Methanol-to-oil mole ratio & $\mathrm{X}_{1}$ & $5.0: 1$ & $6.0: 1$ & $7.0: 1$ & $8.0: 1$ & $9.0: 1$ \\
\hline Catalyst weight (grams) & $\mathrm{X}_{2}$ & 0.80 & 0.90 & 1.00 & 1.10 & 1.20 \\
\hline Temperature $\left({ }^{\circ} \mathrm{C}\right)$ & $\mathrm{X}_{3}$ & 30 & 34 & 38 & 42 & 46 \\
\hline Reaction time (minutes) & $\mathrm{X}_{4}$ & 20 & 25 & 30 & 35 & 40 \\
\hline
\end{tabular}

\section{Free Fatty Acid Reduction Procedure}

The oil was first heated to $100^{\circ} \mathrm{C}$ and then cooled to remove any water content present in the oil. The neem oil had a high free fatty acid value. The free fatty acid reduction of the neem oil was done via esterification of the oil with methanol in the presence of tetraoxosulphate (VI) $\operatorname{acid}\left(\mathrm{H}_{2} \mathrm{SO}_{4}\right)$ as catalyst. The esterification was done in batches. $450 \mathrm{~g}$ of the oil was poured into a 1-litre capacity conical flask and heated to a temperature of $60^{\circ} \mathrm{C}$ while stirring at $1000 \mathrm{rpm} .1 \% \mathrm{w} / \mathrm{w}$ acid was mixed with $30 \% \mathrm{w} / \mathrm{w}$ methanol and the mixture was heated to temperature of $60^{\circ} \mathrm{C}$.

The methanol-acid mixture was added to the heated oil and the conical flask was sealed with a foil. The process was allowed to take place for one hour for the acid esterification to take place. After the esterification process, the acid value was determined to ensure that it is below maximum acceptable limit specified by the ASTM standard. The procedure was repeated for all the batches of the oil sample.

\section{Alkaline catalyzed transesterification}

The oil was first heated to $100^{\circ} \mathrm{C}$ for 10 minutes and then cooled to remove any water content present in the oil. For the first run, 100g of the esterified neem oil was weighed using an electronic weighing balance and poured into a conical flask which served as a continuously stirred reactor. The reactor was initially charged with only the neem oil and heated up to $34^{\circ} \mathrm{C}$. The hot plate was set to give a stirring speed of 400rpm. 0.9 grams of sodium hydroxide were dissolved in 68.06 grams of methanol. To this solution was added $85.93 \mathrm{~cm}^{3}$ of diethyl ether. The resulting solution was added to the oil being stirred in the conical flask at $34^{\circ} \mathrm{C}$. The reaction was allowed to proceed for 25 minutes. The mixture was poured into a separating funnel and allowed to stand overnight to ensure complete separation of methyl esters and glycerol phase. The layer on the top was the biodiesel while the bottom layer was the glycerol. The procedure was repeated for other combination settings from the guidelines established by the experimental design as shown in table 2 .

The glycerol phase (bottom phase) was drained off from the separation funnel and collected in a separate container.

\section{Biodiesel washing and drying}

The methyl ester (biodiesel) was continuously washed with hot distilled water at $80^{\circ} \mathrm{C}$ to eliminate residual catalyst, glycerol, methanol and diethyl ether retained in the biodiesel. 
The biodiesel was then heated at $383 \mathrm{k}$ in a fume cupboard to remove retained methanol, catalyst, diethyl ether and water.

The mass of the biodiesel obtained was determined and recorded in Table 2. The procedure was repeated for all the 30 experimental runs.

Statistical Modelling of the biodiesel production

Where,

$$
Y=a_{0}+\sum_{j=1}^{k} a_{i} X_{i}+\sum_{j=1}^{k} a_{i i} X_{i}^{2}+\sum_{i<j}^{k} \sum_{i j}^{k} a_{i} X_{i} X_{j}^{+}
$$

$\mathrm{Y}$ is response factor (\% yield), $\mathrm{i}$ and $\mathrm{j}$ are integers, $\mathrm{k}$ is the number of independent variables involved, $\mathrm{a}_{0}$ is the intercept term, $\mathrm{a}_{\mathrm{i}}$ are the first order model coefficients for the ith factors, $a_{i i}$ are the second order model coefficient for the ith factor,

$\mathrm{a}_{\mathrm{ij}}$ are regression coefficients of double factor interactions and e is the experimental error. The independent variables which were used were coded according to equation 2 .

$x i=\frac{X i-\frac{X a+X b}{2}}{\frac{X a-X b}{2}}$

$$
\mathrm{i}=1,2,3, \ldots, \mathrm{k}
$$

where, $x i_{\text {is }}$ the coded value symbol for the ith factor while $X i$ is the corresponding natural or real factor value symbol for the ith factor. $X a$ and $X b_{\text {represent the minimum and maximum values of natural variable }} X i$ respectively.

The fitted quadratic response model is show in Equation 3.

$\hat{Y}=72.55-2.93 x_{1}-0.75 x_{2}+0.77 x_{3}-1.62 x_{4}+0.51 x_{1}^{2}-1.38 x_{2}^{2}+5.14 x_{3}^{2}+0.84 x_{4}^{2}-0.65 x_{1} x_{2}-1.07 x_{1} x_{3}-1.20 x_{1} x_{4}-2.07$

$x_{2} x_{3}+3.05 x_{2} x_{4}-1.77 x_{3} x_{4}$

The quality of the fit of the model was evaluated using analysis of variance (ANOVA) as shown in table 3. 
Table.2: Experimental Results for the Central Composite Design

\begin{tabular}{|c|c|c|c|c|c|c|c|c|c|c|c|}
\hline & $\begin{array}{l}\text { Methar } \\
\text { molar } ~ \\
\text { (W/W) }\end{array}$ & $\begin{array}{l}\text { /oil } \\
\text { io \% } \\
\left(\mathbf{X}_{1}\right)\end{array}$ & $\begin{array}{l}\text { Cataly } \\
\% \\
\left(\mathbf{X}_{2}\right)\end{array}$ & weight & $\begin{array}{l}\text { Tempe } \\
\left(\mathbf{X}_{3}\right)\end{array}$ & $\operatorname{ire}\left({ }^{\circ} \mathrm{C}\right)$ & $\begin{array}{l}\text { Time } \\
\left(\mathbf{X}_{4}\right)\end{array}$ & & $\begin{array}{l}\text { Biodic } \\
\text { w/w }\end{array}$ & Yield & \\
\hline $\begin{array}{l}\text { Run } \\
\text { Order }\end{array}$ & $\begin{array}{l}\text { Coded } \\
\text { Value }\end{array}$ & $\begin{array}{l}\text { Real } \\
\text { Value }\end{array}$ & $\begin{array}{l}\text { Coded } \\
\text { Value }\end{array}$ & $\begin{array}{l}\text { Real } \\
\text { Value }\end{array}$ & $\begin{array}{l}\text { Coded } \\
\text { Value }\end{array}$ & $\begin{array}{l}\text { Real } \\
\text { Value }\end{array}$ & $\begin{array}{l}\text { Coded } \\
\text { Value }\end{array}$ & $\begin{array}{l}\text { Real } \\
\text { Value }\end{array}$ & $\begin{array}{l}\text { Exp. } \\
\text { Value }\end{array}$ & $\begin{array}{l}\text { Pred. } \\
\text { Value }\end{array}$ & Residual \\
\hline 1 & -1 & 6.0 & -1 & 0.90 & -1 & 34 & -1 & 25 & 79.10 & 78.47 & 0.63 \\
\hline 2 & 1 & 8.0 & -1 & 0.90 & -1 & 34 & -1 & 25 & 78.70 & 78.47 & 0.23 \\
\hline 3 & -1 & 6.0 & 1 & 1.10 & -1 & 34 & -1 & 25 & 76.10 & 76.33 & -0.23 \\
\hline 4 & 1 & 8.0 & 1 & 1.10 & -1 & 34 & -1 & 25 & 73.27 & 73.70 & -0.43 \\
\hline 5 & -1 & 6.0 & -1 & 0.90 & 1 & 42 & -1 & 25 & 89.04 & 89.84 & -0.80 \\
\hline 6 & 1 & 8.0 & -1 & 0.90 & 1 & 42 & -1 & 25 & 86.00 & 85.56 & -0.44 \\
\hline 7 & -1 & 6.0 & 1 & 1.10 & 1 & 42 & -1 & 25 & 80.16 & 79.40 & 0.76 \\
\hline 8 & 1 & 8.0 & 1 & 1.10 & 1 & 42 & -1 & 25 & 73.33 & 72.50 & 0.83 \\
\hline 9 & -1 & 6.0 & -1 & 0.90 & -1 & 34 & 1 & 35 & 74.35 & 75.07 & -0.72 \\
\hline 10 & 1 & 8.0 & -1 & 0.90 & -1 & 34 & 1 & 35 & 69.60 & 70.26 & -0.66 \\
\hline 11 & -1 & 6.0 & 1 & 1.10 & -1 & 34 & 1 & 35 & 84.80 & 85.14 & -0.34 \\
\hline 12 & 1 & 8.0 & 1 & 1.10 & -1 & 34 & 1 & 35 & 78.62 & 77.70 & 0.92 \\
\hline 13 & -1 & 6.0 & -1 & 0.90 & 1 & 42 & 1 & 35 & 79.90 & 79.36 & 0.54 \\
\hline 14 & 1 & 8.0 & -1 & 0.90 & 1 & 42 & 1 & 35 & 70.61 & 70.27 & 0.34 \\
\hline 15 & -1 & 6.0 & 1 & 1.10 & 1 & 42 & 1 & 35 & 81.01 & 81.13 & -0.12 \\
\hline 16 & 1 & 8.0 & 1 & 1.10 & 1 & 42 & 1 & 35 & 68.89 & 69.42 & -0.53 \\
\hline 17 & -2 & 5.0 & 0 & 1.00 & 0 & 38 & 0 & 30 & 80.70 & 80.46 & 0.24 \\
\hline 18 & 2 & 9.0 & 0 & 1.00 & 0 & 38 & 0 & 30 & 68.28 & 68.74 & -0.46 \\
\hline 19 & 0 & 7.0 & -2 & 0.8 & 0 & 38 & 0 & 30 & 68.63 & 68.52 & 0.11 \\
\hline 20 & 0 & 7.0 & 2 & 1.2 & 0 & 38 & 0 & 30 & 65.20 & 65.53 & -0.33 \\
\hline 21 & 0 & 7.0 & 0 & 1.00 & -2 & 30 & 0 & 30 & 91.99 & 91.58 & 0.41 \\
\hline 22 & 0 & 7.0 & 0 & 1.00 & 2 & 46 & 0 & 30 & 94.04 & 94.67 & -0.63 \\
\hline 23 & 0 & 7.0 & 0 & 1.00 & 0 & 38 & -2 & 20 & 78.53 & 79.14 & -0.61 \\
\hline 24 & 0 & 7.0 & 0 & 1.00 & 0 & 38 & -2 & 40 & 73.05 & 72.66 & 0.39 \\
\hline 25 & 0 & 7.0 & 0 & 1.00 & 0 & 38 & 0 & 30 & 72.52 & 72.55 & -0.03 \\
\hline 26 & 0 & 7.0 & 0 & 1.00 & 0 & 38 & 0 & 30 & 73.04 & 72.55 & 0.49 \\
\hline 27 & 0 & 7.0 & 0 & 1.00 & 0 & 38 & 0 & 30 & 72.60 & 72.55 & 0.05 \\
\hline 28 & 0 & 7.0 & 0 & 1.00 & 0 & 38 & 0 & 30 & 71.88 & 72.55 & -0.67 \\
\hline 29 & 0 & 7.0 & 0 & 1.00 & 0 & 38 & 0 & 30 & 72.17 & 72.55 & -0.38 \\
\hline 30 & 0 & 7.0 & 0 & 1.00 & 0 & 38 & 0 & 30 & 73.08 & 72.55 & 0.53 \\
\hline
\end{tabular}

Table.3: Analysis of Variance for the Response Surface Model

\begin{tabular}{|c|c|c|c|c|c|c|}
\hline $\begin{array}{l}\text { Source of } \\
\text { Variables }\end{array}$ & $\begin{array}{c}\text { Sum of } \\
\text { squares }\end{array}$ & DF & Mean squares & F-value & $\begin{array}{l}\text { P-value } \\
\text { Prob> F }\end{array}$ & Comment \\
\hline Model & 1471.1 & 14 & 105.08 & 204.54 & $<0.0001$ & Significant \\
\hline $\mathbf{X}_{1}$ & 208.45 & 1 & 208.45 & 405.76 & $<0.0001$ & Significant \\
\hline $\mathbf{X}_{2}$ & 12.80 & 1 & 12.80 & 24.92 & 0.0002 & Significant \\
\hline $\mathbf{X}_{3}$ & 13.85 & 1 & 13.85 & 26.95 & 0.0001 & Significant \\
\hline $\mathbf{X}_{4}$ & 64.45 & 1 & 64.45 & 125.46 & $<0.0001$ & Significant \\
\hline $\mathbf{X}_{1}{ }^{2}$ & 7.14 & 1 & 7.14 & 13.89 & 0.0020 & Significant \\
\hline $\mathbf{X}_{2}^{2}$ & 52.51 & 1 & 52.51 & 102.22 & $<0.0001$ & Significant \\
\hline $\mathbf{X}_{3}{ }^{2}$ & 721.86 & 1 & 721.86 & 1405.18 & $<0.0001$ & Significant \\
\hline$X_{4}{ }^{2}$ & 19.13 & 1 & 19.13 & 37.24 & $<0.0001$ & Significant \\
\hline $\mathbf{X}_{1} \mathbf{X}_{2}$ & 6.29 & 1 & 6.29 & 12.24 & 0.0032 & Significant \\
\hline $\mathbf{X}_{1} \mathbf{X}_{3}$ & 19.29 & 1 & 19.29 & 37.56 & $<0.0001$ & Significant \\
\hline $\mathbf{X}_{1} \mathbf{X}_{4}$ & 24.23 & 1 & 24.23 & 47.17 & $<0.0001$ & Significant \\
\hline $\mathbf{X}_{2} \mathbf{X}_{3}$ & 67.04 & 1 & 67.04 & 130.49 & $<0.0001$ & Significant \\
\hline $\mathbf{X}_{2} \mathbf{X}_{4}$ & 151.84 & 1 & 151.84 & 295.58 & $<0.0001$ & Significant \\
\hline $\mathbf{X}_{3} \mathbf{X}_{4}$ & 51.73 & 1 & 51.73 & 100.70 & $<0.0001$ & Significant \\
\hline Residual & 7.71 & 15 & 0.51 & & & \\
\hline
\end{tabular}




\begin{tabular}{c|c|c|c|c|c|c|c}
\hline Lack of fit & 6.59 & 10 & 0.66 & 2.95 & 0.1222 & Not Significant \\
$\begin{array}{c}\text { Pure Error } \\
\text { Cor Total }\end{array}$ & 1.12 & 5 & 0.22 & & & \\
\hline
\end{tabular}

\section{Optimization}

The quadratic model was used for optimization with the help of Design Expert software. The optimum values of the independent variable obtained are 6:1 methanol/oil molar ratio, $34^{\circ} \mathrm{C}$ reaction temperature, $1.1 \%$ catalyst concentration, and 35-min reaction time.

\section{Determination of the properties of the biodiesel}

The fuel properties of the neem oil biodiesel were carried out using the ASTM methods and the results are presented in table 4 . The properties determined include: Physical state at $25^{\circ} \mathrm{C}$, Colour, moisture content, acid value, \% FFA, specific gravity @ 25 $5^{\circ}$,iodine value, saponification value, kinematic viscosity @ 40, , flash point(closed cup), cloud point, pour point and cetane number.

\section{Chromatography - Mass Spectrometry (GC-MS) Analysis}

The presence of methyl ester in the biodiesel was determined using a Gas Chromatography - Mass Spectrometry (GC-MS) machine.

\section{RESULTS AND DISCUSSION}

Results of Characterization of Neem Oil and Biodiesel

The neem oil was seen to have high acid content after its characterization which necessitated the pre-treatment of the oil through esterification before the transesterification process. The result of characterization of the neem oil also revealed that the neem oil has a relatively high iodine value which implies that the biodiesel produced from the neem oil has the tendency to undergo oxidation and polymerization and when stored for a very long time.

\section{Analysis of Variance for the Response Surface Model}

The results of analysis of variance (ANOVA) for the response surface model are shown in Table 3. The result shows that the model has a high F-ratio(i.e F-value). From table 3, the calculated F-value for the model(204.54) is greater than the tabulated critical value (2.42). The large Fvalue of the model(204.54) implies that the model is significant. The associated P-value of 0.0001 implies that there is only a $0.01 \%$ chance that the Model "F-value" this large could occur due to noise. "Prob > F" for each of the model terms is less than 0.05 which indicates that the terms in the model have a significant effect on the response. In this case $\mathrm{X}_{1}, \mathrm{X}_{2}, \mathrm{X}_{3}, \mathrm{X}_{4}, \mathrm{X}_{1}^{2}, \mathrm{X}_{2}^{2}, \mathrm{X}_{3}^{2}, \mathrm{X}_{4}^{2}, \mathrm{X}_{1} \mathrm{X}_{2}, \mathrm{X}_{1} \mathrm{X}_{3}$, $\mathrm{X}_{1} \mathrm{X}_{4}, \mathrm{X}_{2} \mathrm{X}_{3}, \mathrm{X}_{2} \mathrm{X}_{4}, \mathrm{X}_{3} \mathrm{X}_{4}$ are significant model terms. The "Lack of Fit F-value" of 3.08 implies the Lack of Fit is not significant relative to the pure error. The "Prob > F" value associated with the lack of fit implies that there is a $12.22 \%$ chance that a "Lack of Fit F-value" this large could occur due to noise. The Non-significant lack of fit is good as it is desired for the model to fit the data well.

\section{Model Summary Statistics}

Table 5 contains the result of the model summary statistics. The Coefficient of determination(R-Squared $=0.9948$ ) shows that the fit of the model is good. The closer the value to unity, the better the empirical model fits the actual data. It implies that $99.48 \%$ of the total variability in the response is explained by the model. The "Pred. R-Squared" of 0.9733 is in reasonable agreement with the "Adj R-Squared" of 0.9899 which shows high accuracy of the model in predicting the yield of the biodiesel for given factor combination settings. The Adj. R-Squared is a statistic that is adjusted for the "size" of the model, i.e the number of factors. The Adj. R-Squared value can actually decrease if non-significant terms are added to a model. The PRESS Statistic is a measure of how well the model will predict new data. The low prediction error sum of squares(PRESS) value indicates that the model is likely to be a good predicator.

Comparison of the Biodiesel Properties with the ASTM Standards

The biodiesel was characterized in terms of moisture content, specific gravity, acid value, iodine value, saponification value, ester value cloud point, pour point, kinematic viscosity, flash point and cetane number. The results are presented in Table 4 . The values obtained were compared to the ASTM specifications. All the properties met the ASTM specifications except the flash point $\left(134^{\circ} \mathrm{C}\right)$. The high flash point could be attributed to the presence of retained di-ethyl ether in the fuel. Fuels with flash point higher than specifications in ASTM standards pose hazards during storage and transportation. Better means of removing the retained co-solvent should be employed in large scale production of the neem biodiesel using co-solvent technique. The low moisture content and acid value of the 
neem biodiesel is desirable as it will prevent corrosion of the fuels to engine parts and growth of micro-organisms. The acid value is below the lower limit which makes it safe for use in diesel engine. The density value of the neem biodiesel was obtained to be $0.8881 \mathrm{~kg} / \mathrm{m}^{3}$ which falls within the ASTM acceptable limits. The kinematic viscosity, which determines how well the fuel is atomized prior to combustion, is seen to meet the ASTM standard. The low pour point will allow the fuel to be used in extremely cold weather conditions without gelling and blocking fuel filters and fuel lines. The cetane number also falls within the ASTM specification. This property shows that the neem biodiesel has a good quality as fuels with high cetane numbers burn smoothly and more efficiently than fuels with low cetane number

\section{Experimental Results for the Central Composite Design}

Table 1 shows the design considered in this study in terms of coded and natural values. The experiment was carried out based on the design guidelines in table 1. The methanol: diethyl ether volume ratio of 1:1 was used based on the optimum established results obtained in previous works involving co-solvent technology transesterification (Mohammed, 2012). The experimental results and the predicted values are also recorded. The optimum yield obtained in this study $(84.77 \mathrm{w} / \mathrm{w})$ is in comparison with $85.13 \%$ obtained in literature for the alkaline catalysed transesterification using the conventional method(Awolu et al., 2013).

The values of the predicted yield using the fitted quadratic model are compared to the experimental results and the residuals recorded as seen in table 2 . The small values of the residuals indicate that the model fits the experimental data well.

The optimum yield (w/w) was obtained to be 84.77 grams at optimum variable values of $6.00: 1$ for methanol-to-oil volume ratio, 1.10 grams for catalyst weight, $34.00^{\circ} \mathrm{C}$ for reaction temperatures and 35.00 minutes for reaction time. The optimum time obtained in this study is in agreement with that obtained by Felicia et al, 2014. The lower yield of biodiesel compared to those in literature could be as a result of excessive addition of the diethyl ether for the reaction leading to dilution effect of the reactants.

Table.4: Comparison of the Biodiesel Properties with the ASTM Standards

\begin{tabular}{|c|c|c|c|c|c|}
\hline $\mathbf{S} / \mathbf{n}$ & Properties & Units & $\begin{array}{l}\text { ASTM Test } \\
\text { method }\end{array}$ & $\begin{array}{l}\text { Neem Biodiesel } \\
\text { values }\end{array}$ & $\begin{array}{l}\text { ASTM D675 } \\
\text { specification }\end{array}$ \\
\hline $\mathbf{1}$ & Physical state at $25^{\circ} \mathrm{C}$ & - & - & Liquid & - \\
\hline 2 & Colour & - & - & Reddish Brown & - \\
\hline 3 & Moisture Content & $\% \mathrm{wt}$ & 2709 & 0.04 & $0.05 \max$. \\
\hline 4 & Acid value & $\mathrm{mg} \mathrm{KOH} / \mathrm{g}$ & D664 & 0.491 & $0.05 \max$. \\
\hline 5 & $\%$ FFA & $\%$ & - & 0.246 & - \\
\hline 6 & Specific gravity @ $25^{\circ} \mathrm{C}$ & $\mathrm{kg} / \mathrm{m}^{3}$ & D4052 & 0.8881 & $0.87-0.90$ \\
\hline 7 & Iodine value & mg iodine/g & D1959 & 73.728 & - \\
\hline 8 & Saponification value & $\mathrm{mg} \mathrm{KOH} / \mathrm{g}$ & AOAC Cd 3-25 & 193.195 & - \\
\hline 9 & Kinematic viscosity@40 & $\mathrm{mm}^{2} / \mathrm{s}$ & D2983 & 5.86 & $1.9-6.0$ \\
\hline 10 & Flash point(closed cup) & ${ }^{0} \mathrm{C}$ & D93 & 134 & $130 \mathrm{~min}$ \\
\hline 11 & Cloud point & ${ }^{0} \mathrm{C}$ & D2500 & 7 & -3 to 12 \\
\hline 12 & Pour point & ${ }^{0} \mathrm{C}$ & D97 & 4 & -5 to 10 \\
\hline 13 & Cetane number & $\min$ & D613 & 51.733 & $47 \min$ \\
\hline
\end{tabular}

Table.5: Model Summary Statistics

\begin{tabular}{|l|l|l|}
\hline S/n & Statistic & Value \\
\hline $\mathbf{1}$ & Standard Deviation & $\mathbf{0 . 7 2}$ \\
$\mathbf{2}$ & Mean & $\mathbf{7 6 . 6 2}$ \\
$\mathbf{3}$ & C.V\% & $\mathbf{0 . 9 4}$ \\
$\mathbf{4}$ & Press & $\mathbf{3 9 . 5 6}$ \\
$\mathbf{5}$ & R-Squared & $\mathbf{0 . 9 9 4 8}$ \\
$\mathbf{6}$ & Adjusted R-Squared & $\mathbf{0 . 9 8 9 9}$ \\
7 & Pred R-Squared & $\mathbf{0 . 9 7 3 3}$ \\
$\mathbf{8}$ & Adeq precision & $\mathbf{5 7 . 2 8 9}$ \\
\hline
\end{tabular}




\section{CONCLUSION}

The maximum neem oil methyl ester (NOME) conversion yield was validated as $84.77 \%(\mathrm{w} / \mathrm{w})$ under the optimal reaction condition of $6: 1$ methanol/oil molar ratio, $34^{\circ} \mathrm{C}$ reaction temperature, $1.1 \%$ catalyst concentration, and 35 min reaction time. The fuel properties of neem oil methyl ester satisfied the ASTM D6751 specification. The present study demonstrates the importance of economic effect of biodiesel production from neem oil using co-solvent technique. It also suggests that neem biodiesel can be produced at lower cost in the presence of diethyl ether solvent.

\section{REFERENCES}

[1] Prerna G., Sharma M.P., and Sidhart J. (2012). Optimization of Esterification and Transesterification of High FFA Jatropha Curcas Oil Using Response Surface Methodology. Journal of Petroleum Science Research, Vol. 1 Iss. 3, PP. 36-43.

[2] Mohammed D. I. A., Ahmad M. S., Hamza A., Muazu Aand Aliyu A. (2012).

[3] Co-solvent transesterification of Jatropha curcasseed oil. Journal of Petroleum Technology and Alternative Fuels Vol. 3(4), pp. 42-51.

[4] Biodiesel Handling and Use Guide. Fourth Edition(2009).

[5] Rajarshi K., Oindrila G., Mukundu K., (2012). Biodiesel Production and Process Optimization. DasInternational Journal of Scientific and Research Publications, Volume 2, Issue 6.

[6] Felicia, Falentina F. and Taslim (2014). Biodiesel Production From Chicken Fat Using Diethyl Ether As Co-Solvent.Proceedings of The 5th Sriwijaya International Seminar on Energy and Environmental Science \& Technology Palembang, Indonesia.

[7] Awolu O. O. and Layokun S. K. (2013). Optimization of two-step transesterification production of biodiesel from neem(Azadirachta indica) oil. International Journal of Energy and Environmental Engineering, 4:39.

[8] Refaat A. A.; Attia N. K.; Sibak H. A.; El Sheltawy S. T and ElDiwani G. I. (2008)

[9] Production optimization and quality assessment of biodiesel fromwaste vegetable oil.Int. J. Environ. Sci. Tech., 5 (1), 75-82.

[10] Musa U.,Aboje A.A., Mohammed I. A., Aliyu M. A., Sadiq M. M. and Olaibi A. O. (2014). The Effect of Process Variables on the transesterification of Refined
Cottonseed Oil. Proceedings of the World Congress on Engineering, Vol I.

[11] Narupon J., Chattip P., Motonobu G., Mitsuru S and Artiwan S. Effect of Co-solvents on Transesterification of Refined Palm Oil in Supercritical Methanol. Engineering journal, volume 15 , Issue 3.

[12] Pinto, A. C., Guarieiro, L. N., Rezende, M. J., Ribeiro, N. M., Torres, E. A., Lopes, W. A., Pereira, P. A. \& Andrade, J. B. (2005). Biodiesel. An overview. J. Brazil. Chem. Soc., 16(6B), 1313-1330.

[13] Encinar, J. M., Juan, F., Gonzalez, J. F., \& RodriguezReinares, A. (2007).

[14] Ethanolysis of used frying oils: Biodiesel preparation and Characterization. Fuel Process. Tech., 88(5), 513522

[15] Aransiola, E. F., Ojumu, T. V., Oyekola, O. O., \& Ikhuomoregbe, D. I. O. (2012). A case of Biodiesel Production from Non-Edible Oil Seeds: A Comparative Study. The Open Conference Proceedings Journal, 3, 1-5. 